\title{
Brand preference of farmers and dealers towards Bt cotton hybrid seeds in Guntur district of Andhra Pradesh
}

\author{
SHRAVAN KUMAR GOGULAMANDA, T. SAMSAI AND S. PRAVEENA
}

Received : 25.05.2017; Revised : 05.08.2017; Accepted : 19.08.2017

\begin{abstract}
Cotton is considered to be an important cash crop in the agrarian economy of India. India is the second largest exporter of cotton after China with an annual export of 7.5 billion US dollars. India is the only country to grow all the four species of cultivated cotton. Due to various factors, the productivity of cotton is very low in the country when compared to the world average productivity. Brand preference in hybrid seeds is one of the factors that directly affects the farmers and influences the productivity of cotton. The present study focuses on the Brand preference of farmers and dealers towards the bt cotton hybrid seeds. Totally 50 farmers and 20 dealers were selected by simple random sampling method. Percentage analysis, Garrett ranking and Standard deviation were used for the analysis of the study. From the results it could be concluded that most of the farmers well aware about the Bt cotton in the study area. Major share of the sample farmer respondents were old aged persons and they are illiterates. Moreover, a majority of the dealers are above the age group of 50 years and well experienced in the marketing of seeds. Cost of seeds and influence of dealers are the main factors influencing the purchase of the hybrid seeds.
\end{abstract}

KEY WORDS : Awareness, Brand preference, Cotton, Constraints, Market share

How to cite this paper : Gogulamanda, Shravan Kumar, Samsai, T. and Praveena, S. (2017). Brand preference of farmers and dealers towards Bt cotton hybrid seeds in Guntur district of Andhra Pradesh. Internat. J. Com. \& Bus. Manage, 10(2) : 83-88, DOI: 10.15740/ HAS/IJCBM/10.2/83-88.

\section{MEMBERS OF THE RESEARCH FORUM}

Correspondence to:

S. PRAVEENA, Department of Agriculture and Rural Management, Tamil Nadu Agricultural University, COIMBATORE (T.N.) INDIA

Email : sspriyamba@gmail.com

Authors' affiliations:

SHRAVAN KUMAR GOGULAMANDA AND T. SAMSAI, Department of Agriculture and Rural Management, Tamil Nadu Agricultural University, COIMBATORE (T.N.) INDIA 